Pedagogy: Journal of English Language Teaching

Volume 9, Number 2, December 2021

E-ISSN: 2580-1473 \& P-ISSN: 2338-882X

Published by Institut Agama Islam Negeri Metro

\title{
Investigating EFL Master Students' Beliefs and Practices Regarding Reader Engagement in Writing Research Articles
}

\author{
ARTICLE INFO \\ Article history: \\ Received \\ January 21st, 2021 \\ Revised \\ July $18^{\text {th }}, 2021$ \\ Accepted \\ October $12^{\text {th }}, 2021$
}

\author{
Anis Handayani \\ Universitas Sebelas Maret, Indonesia \\ Email: anishandayani@student.uns.ac.id
}

\begin{abstract}
This study reports Indonesian master students' beliefs and practices on the use of reader engagement in writing research articles. This study was a case study conducted in one Indonesian university. The data were collected through questionnaires, in-depth interviews, and document analysis. The participants were 23 Indonesian master students. Furthermore, there were 9 research articles written by the participants which were analyzed in this study. The data were analyzed under metadiscourse framework, specifically in the reader engagement: reader pronouns, personal asides, appeals to shared knowledge, directives, and questions. The findings show that Indonesian master students believe in the importance of using reader engagement in research articles. However, they rarely used it since they did not know the concept and how to use it effectively. It implies that more exposure of using metadiscourse, especially reader engagement, in research articles is needed for Indonesian master students to achieve more reader-friendly research articles.
\end{abstract}

Keywords: academic writing; beliefs; reader engagement; metadiscourse; research articles

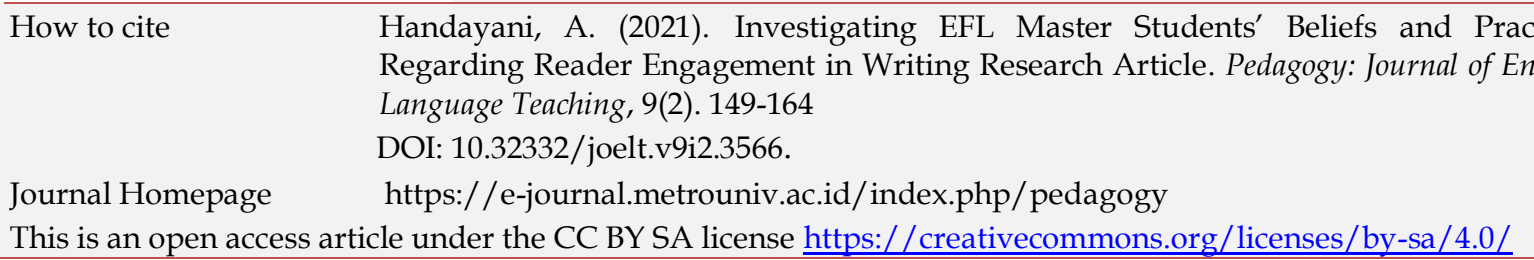

Handayani, A.| Investigating EFL Master Students' Beliefs and Practices..., 149-164 


\section{INTRODUCTION}

Writing is not static (Hyland, 2005b). It has an interaction between the writer and the readers. Hyland (2005c) views writing as a discourse where the writer and readers interact through the text. It is what he calls as interactional metadiscourse which refers to the ways the writer presents himself and the readers in the text. There are two elements in interactional metadiscourse namely stance and reader engagement. Stance refers to the ways the writers present themselves and convey their judgments, opinions, and commitments while engagement is a way to build a relationship between the writer and the readers. This reader engagement refers to ways writers involve the readers in their writings. Reader engagement is considered as an important aspect in building arguments in academic writing (Jiang \& Ma, 2018; Kuteeva, 2011).

Prior studies have shown that reader engagement is an essential element to take readers into a text as participants in a telling dialogue (Hyland, 2005c). It seems that research is now being reported more impersonally and with less explicit effort to finesse the reader. By using reader engagement, writers take into consideration of their readers' background knowledge, interests, and interpersonal expectations to guide them into the intended aims of the text (Hyland, 2005c). Due to its importance, researchers have taken reader engagement and metadiscourse as a research interest over years.

Many researchers have studied metadiscourse in various types of writings, such as research abstracts (Gillaerts \& Velde, 2010), postgraduate writing (Can \& Cangır, 2019; Hyland, 2004; Loghmani et al., 2020), argumentative essays (Handayani et al., 2020; Ho \& Li, 2018; Lee \& Deakin, 2016). However, there was rarely any study focusing on the beliefs on using metadiscourse, especially on the use of reader engagement, in research articles. Furthermore, in Indonesia, in which the current study took place, the use of metadiscourse in research articles is limited. It brings us curiosity over their beliefs on the use of reader engagement in research articles and whether they neglect it in actual practices. Therefore, to fulfill this gap, this current study tries to find Indonesian master students' beliefs and practices on the use of reader engagement in research articles. Explicitly stated, the research questions of this current study are formulated as:

1. How is the Indonesian master students' belief on the use of reader engagement in research articles?

2. How is the Indonesian master students' practice on the use of reader engagement in research articles? 
Reader Engagement in Academic Writing

Reader engagement is the way writers put their readers in a position in their writing (Hyland, 2005c). The writers try to recognize the readers' presence in the writing, involve in the arguments, guide them to focus on the writing, acknowledge their uncertainties, include them as active participants, and guide them into the expected interpretation. Here, the writers try to make their readers "important" in the writings. In the process of writing, the writers consider who their expected readers are and guide them into the correct interpretation of the writings (Hyland \& Jiang, 2016). Writers are aware that some readers have different views toward the writings, so they try to mediate the writings and the readers' views. It is an essential aspect in research articles in which the writers try to interact and include the readers in the writings (Hyland, 2005a).

Following Hyland (2005c), reader engagement has five elements, namely reader pronouns, personal asides, appeals to shared knowledge, directives, and questions. Reader pronoun is how the writers mention the readers in the writings explicitly. The most commonly used reader pronoun is you (example 1). However, in academic writing, writers mostly use we to acknowledge readers' presence (example 2). Reader pronoun we is used to show solidarity, include them in the discourse, anticipate their objections, voice their concerns, and express their views (Hyland, 2005c). It helps the writers to pull the readers into their views. It makes the writers' views seem to be the readers' views as well.

(1) You can access the website via https://ethos.bl.uk/Home.do.. (Can \& Cang1r, 2019, p.3)

(2) We explore changes in the use of ten Key features regarded by applied linguists and style guide authors as representing informality. (Hyland \& Jiang, 2017, p.40)

The next element is personal asides. It is the writer's personal comments in the writing to maintain the writer-reader relationships. Personal asides are commonly in the form of additional comments entailed in the main sentence. It is used to show that both writer and reader are on the same track and will lead to the same understanding. The examples of personal asides are presented in example 3.

(3) He above all provoked the mistrust of academics, both because of his trenchant opinion (often, it is true, insufficiently thought out) and his political opinions. (Hyland, 2005c, p.183)

Then, appeals to shared knowledge seek to readers within the same or shared knowledge as the writer. It is used to show solidarity by providing knowledge that has the same views as the readers do. In using this reader engagement aspect, the 
writers use words, such as obviously (example 4), of course, and other certainty adverbs.

(4) Obviously, readers can only be brought to agree with the writer by building on some kind of implicit contract concerning what can be accepted, but often these constructions of solidarity involve explicit calls asking readers to identify with particular views. (Hyland, 2005c, p.184)

The next element is directives. These directives are used to instruct the reader to do something determined by the writer. Directives often appear in the form of imperatives such as consider, note, and imagine, obligation modals such as must, should, and ought to, or predictive adjectives expressing the writer judgment of importance such as it is important to understand, it is necessary to.., and so on (Hyland, 2005c). Example 5 and 6 present the examples of directives.

(5) Before attempting to measure the density of the interface states, one should freeze the motion of charges in the insulator. (Hyland, 2005c, p.185)

(6) It is important to note that these results do indeed warrant the view that ... (Hyland, 2005c, p.185)

The last element is questions. Writers use questions to arouse readers' curiosity and lead them into the writer's views. It allows the readers to involve in the writer's views by thinking about the problem as an equal participant in the discourse as the writer. However, the questions are often rhetoric. The writer expects no answer from the readers. It is merely used to arouse the reader's interest in the writings (Hyland, 2005c). Besides, the writers often provide the answer right after the question. The example is presented in example 7.

(7) What role do frame markers play in organising discourse for particular target readers? (Hyland \& Zou, 2020, p.32)

As explained, reader engagement takes role in creating more reader-friendly writings. Writers make use of this linguistic feature to involve the readers, guide them along with the writings, and make sure the readers get the intended aims of the writings. It is surely an essential factor to achieve successful research articles in which the readers will have the same interpretation as the writers.

\section{METHOD}

This qualitative case study was conducted in one Indonesian university. The participants are 23 Indonesian master students in English Education major. To gain detailed information and confirmation of the results of the questionnaires, in-depth interviews were conducted with 5 selected participants based on their writing experience. The 
participants have 1-2 years of writing experience. Furthermore, to gain information about their writing practices, we analysed 9 research articles written by the participants ( 2 or 3 students wrote 1 research article).

The data were collected through questionnaires, in-depth interviews, and document analysis. The questionnaires were delivered in Google form to the 23 participants and used to find out the participants' beliefs on the use of reader engagement in research articles. Then, the 5 selected participants were interviewed to make a confirmation and add more detailed information regarding their statements in the questionnaire. Last, the 9 research articles written by the participants were analysed to know the practice of using reader engagement in research articles.

The quantitative data, which is the questionnaire results, were presented in pie charts to ease the interpretation process. Then, the interview data were analysed using interactive models (Miles et al., 2014). After conducting the interviews, the transcripts were generated to make the interpretation easier. Then, the transcripts were simplified, under the themes of five reader engagement elements, to gain necessary data. The results were, then, put in the form of description -extended text. Lastly, the last activity is conclusion drawing and verification.
The data of research articles were coded under five themes of reader engagement elements namely reader pronoun, personal asides, appeals to shared knowledge, directives, and questions. Extract 1 shows the example of the coding.

\section{Extract 1}

The question taken from university 4 admission test requires the students to analyze the relationship between the parts before and after the word to build the context of the text before finding the synonym to the word provided. (See table 2 (directives))

After all 9 articles were coded, the results were compared to the interview results to draw the final conclusion.

\section{RESULTS AND DISCUSSION Results}

To gain a better understanding of the findings, the data were analysed under the title of two research questions.

\section{Research Question 1: Indonesian master students' beliefs on the use of reader engagement in research articles}

Each element of reader engagement has its function in persuasive writings, especially in research article writings. The participants' beliefs on the use of reader engagement in research articles are inferred from the first question of each element in the questionnaires. Furthermore, it gets additional and more detailed information from the in-depth interview with the 5 selected participants. 
The first element of reader engagement is reader pronoun. It is how the writer mentions the readers explicitly in his writing to acknowledge the readers' presence and include them in the discourse. The examples of reader pronoun are personal pronouns you and we. Figure 1 shows that the majority of the participants agree that using reader pronouns is important in writing research articles. They used reader pronouns to include the readers in their writings and acknowledge the readers' presence (see extract 2).

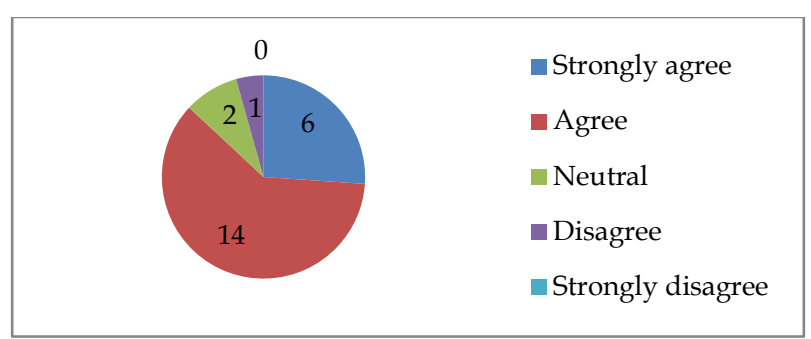

Figure 1. The participants' responses on the importance of using reader pronouns in research

\section{Extract 2} articles

"In my writing, pronoun we is used to directly mention the reader so that they feel that they are also involved in the discussion (in my writings)". (Participant B)

However, some participants stated that it was not significantly important to use reader pronouns in research articles. They said that sometimes the use of reader pronouns reflects the writer's subjectivity. Furthermore, a participant disagreed with the use of reader pronouns in research articles. He said that it would make his writings seem informal (see extract 3 ).

\section{Extract 3}

"If I use pronouns we, you, my writing will look informal". (Participant A)

The second element of reader engagement is personal asides. Personal asides are the writer's personal comments in the writing to maintain the writerreader relationships. It is used to show that both writer and reader are on the same track and will lead to the same understanding. The example of personal pronouns is "And -as I believe many TESOL professionals will readily acknowledge-critical thinking has now begun to make its mark, particularly in the area of L2 composition" (Hyland, 2005c, p.183).

The result of the questionnaires shows that the majority of the participants agree that using personal asides is important in writing research articles (see Figure 2). It means that the participants somehow agree to the use of personal asides in writing their research articles.

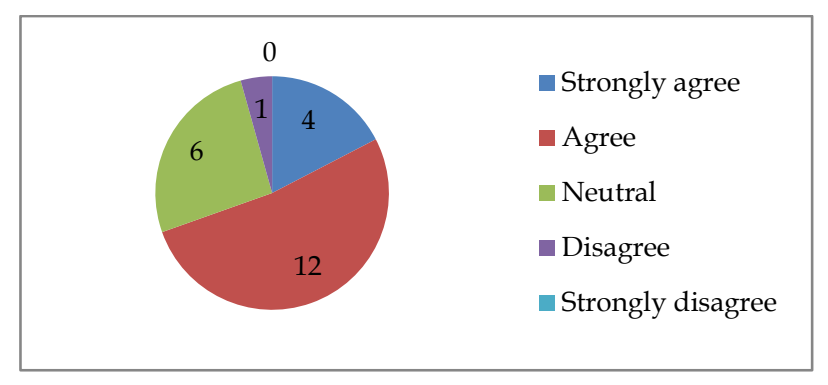

Figure 2. The participants' responses on the importance of using personal asides in research articles 
However, from the in-depth interview, it is inferred that some participants have misunderstandings on the concept of personal asides. They said that it was to show the writer's argument when it was actually used to give more explanation in order to keep the readers on the same track as the writer. One participant disagreed with the use of personal asides in research articles. He said that it was not really important to add personal comments in research articles (see extract 4). Furthermore, he also added that he got confused about how to express his personal comments so that they looked 'fit' in the research articles.

\section{Extract 4}

"I don't really understand how to write my personal comments in my writing, but I think it will be fine even if I don't include it (so I didn't use personal asides)." (Participant B)

The third element of reader engagement is appeals to shared knowledge. Appeals to shared knowledge seek the readers within the same or shared knowledge as the writer. It is used to show solidarity by providing knowledge which has the same views as the readers do. In using appeals to shared knowledge, the writers use words such as obviously, of course, and other certainty adverbs. The result of the questionnaires shows that most participants agreed with the importance of using appeals to shared knowledge in research articles (see Figure 3).

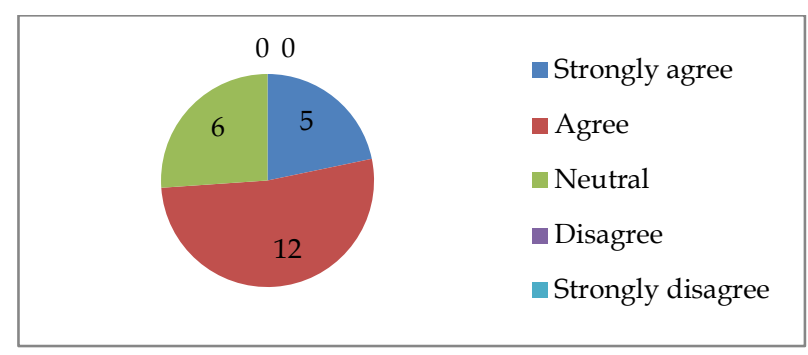

Figure 3. The participants' responses on the importance of using appeals to shared knowledge in research articles

Furthermore, the students stated that the use of obviously, of course, and other certainty expression made the readers automatically agree to their statements in research articles. However, some participants stated that using appeals to shared knowledge was not really important in research articles. Some said they had little confidence in their arguments that they neglected using these appeals to shared knowledge (see extract 5).

\section{Extract 5}

"I'm not sure if my claim is right, so I don't use expressions such as surely, certainly, etc." (Participant E)

The fourth element of reader engagement is directives. Directives are used to instruct the reader to do something determined by the writer. Directives are commonly in the form of imperatives such as consider, note, and imagine, obligation modals such as must, should, and ought to, or predictive adjectives expressing the writer judgment of importance such as it is important to 
understand, it is necessary to.., and so on. The result of the questionnaires shows that most participants agree that using directives in research articles is important (see figure 4).

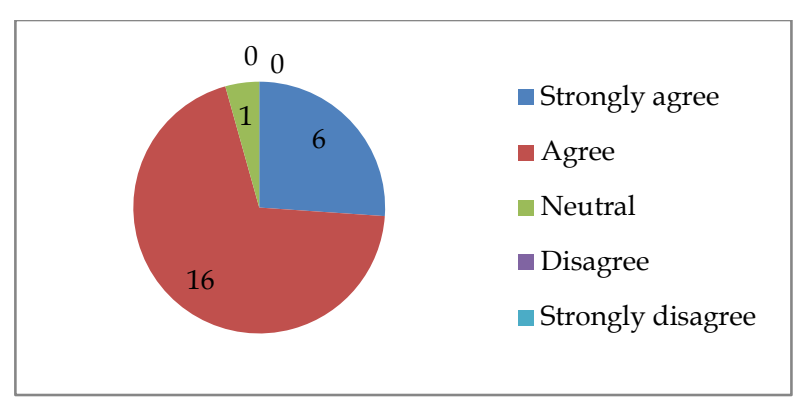

Figure 4. The participants' responses on the importance of using directives in research articles

Furthermore, they stated that it used to guide the readers so that they understood more about the topic the writer conveys. Some said 'it is important to ..." expression was used to emphasize the importance of the topic being discussed (see extract 6). They claimed that it was an important feature used in persuasive writing such as research articles.

\section{Extract 6}

"I used it (directives) to guide my readers so that they can follow my thought and understand what I mean easier". (Participant D)

The last element of reader engagement is questions. Writer uses questions to arouse readers' curiosity and lead them into the writer's views. It allows the readers to involve in the writer's views by thinking the problem as an equal participant in the discourse as the writer.
The result of the questionnaire shows that the majority of the participants agree with the importance of using questions in research articles (see Figure 5).

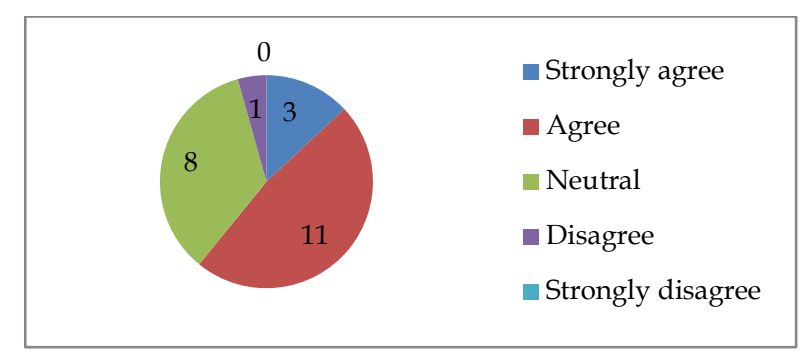

Figure 5. The participants' responses on the importance of using directives in research articles

Furthermore, they stated that questions attract readers' attention to the topic of the writing. Furthermore, it also made the readers included in the discourse by thinking about the topic being discussed (see extract 7). However, some participants preferred staying neutral to the use of questions in research articles. They stated that it only made the writings more varied so they only used it when they felt like to. One participant even disagreed with the idea of using questions in research articles. He stated that it would make the writings informal so he preferred not to use them.

\section{Extract 7}

"Questions in my essay are used to make my readers think about the topic along with my explanation." (Participant D)

In sum, the results of the questionaries show that most participants agree that using reader engagement is important in writing research articles. 
Table 1 summarizes the participants' responses on the importance of using reader engagement in writing their research articles.

Table 1. The summary of participants' responses on the importance of using reader engagement in

\begin{tabular}{cccccc}
\multicolumn{5}{c}{ writing research articles } \\
\hline Engagement $\begin{array}{c}\text { Participants' responses } \\
\text { Elements }\end{array}$ & $\begin{array}{c}\text { Strongly } \\
\text { agree }\end{array}$ & Agree & Neutral & Disagree & $\begin{array}{c}\text { Strongly } \\
\text { disagree }\end{array}$ \\
\hline $\begin{array}{c}\text { Reader } \\
\text { pronoun }\end{array}$ & 6 & 14 & 2 & 1 & 0 \\
$\begin{array}{c}\text { Personal } \\
\text { asides }\end{array}$ & 4 & 12 & 6 & 1 & 0 \\
$\begin{array}{c}\text { Appeals to } \\
\text { shared }\end{array}$ & 5 & 12 & 6 & 0 & 0 \\
knowledge & & & & & \\
$\begin{array}{c}\text { Directives } \\
\text { Questions }\end{array}$ & 6 & 16 & 1 & 0 & 0 \\
\hline
\end{tabular}

However, despite their agreement on the importance of using reader engagement in writing research articles, their interviews reported varied responses. Some participants agreed to the importance of using reader engagement in writing research articles and while some disagreed and were still confused about its function and how to use it effectively that they somehow neglected this linguistic feature in writing their research articles.

\section{Research Question 2: Indonesian master students' practices on the use of reader engagement in research articles}

The use of reader pronouns in research articles

The result of the questionnaires shows that $52.2 \%$ of the participants used reader pronouns in writing research articles. Some participants stated that they used them to show solidarity so that the readers were involved in the discourse. They stated that they agreed to use reader pronoun we, but not you. They claimed that reader pronoun you reflects informality, so they preferred not to use it in writing research articles. Furthermore, they stated that they also used reader pronouns in other academic writings such as procedure text, argumentative essay, cover letter, and so on (see extract 8).

\section{Extract 8}

"I often used this pronoun we when I wrote argumentative essays. It is used to involve the readers." (Participant D)

From the document analysis of the research articles, the participants rarely used reader pronouns. There were only 2 research articles using reader pronouns, article B and G. The forms of reader pronouns used are presented in Table 2.

Table 2. The reader pronouns used in participants' research articles

\begin{tabular}{lll}
\hline Source & Form & Sentence in the article \\
\hline Article & Us & $\begin{array}{l}\text { Those } 4 C \text {, especially critical thinking will } \\
\text { lead us to HOTs. } \\
\text { Before further explanation, we have to know } \\
\text { what HOTs is } \\
\text { These stories are about the experiences of live; } \\
\text { the meaning that was made from the events } \\
\text { we live or imagine in our future lives } \\
\text { (Barkhuizen, 2016) } \\
\text { As we know she also mentioned many } \\
\text { advantages of applying HOTs in assessment } \\
\text { for both the teacher and students } \\
\text { This also relates with the theory of Brown } \\
\text { that for senior high school grades, we can use } \\
\text { the kind of selective-interactive reading as } \\
\text { students' assessment. } \\
\text { Specifically, in this research which focus on } \\
\text { the implementation of HOTs reading } \\
\text { assessment, we can see the major point of }\end{array}$ \\
\end{tabular}




\begin{tabular}{ll}
\hline Article We $\quad \begin{array}{l}\text { using HOTs. } \\
\text { Although there are many studies that have } \\
\text { showed the use of HOTS in the English } \\
\text { teaching and learning, we still know little } \\
\text { about the infusing of HOTS in the English } \\
\text { National Examination and education } \\
\text { assessment }\end{array}$ \\
\hline
\end{tabular}

The use of personal asides in research articles

The result of the questionnaires shows that $60.9 \%$ participants used personal asides in writing research articles. The participants stated that they used it to strengthen their arguments in writing argumentative writings. Some preferred not using it because they did not have confidence in their arguments. Some even still had misunderstanding on the concept of personal asides in academic writing. Despite the high percentage of participants answering 'yes' in using personal asides, the research articles they made do not express the use of personal asides.

The use of appeals to shared knowledge in research articles

The result of the questionnaires shows that $82.6 \%$ of participants used appeals to shared knowledge in writing research articles. The participants stated that they used it to show that the readers had the same views as the writers. Furthermore, they also stated that it was used to persuade that the readers should have understood the topic or the argument. They claimed that they often used it in the research discussion (see extract 9).

\section{Extract 9}

"Since it is used to show shared knowledge, I often find and use it in discussion part of research articles." (Participant D)

From the document analysis of the research articles, the participants rarely used appeals to shared knowledge. There were only 3 research articles using appeals to shared knowledge, article C, G, and I. The forms of appeals to shared knowledge used are presented in table 3 .

Table 3. The appeals to shared knowledge used in participants' research articles

\begin{tabular}{|c|c|c|}
\hline Source & Form & Sentence in the article \\
\hline $\begin{array}{l}\text { Article } \\
\text { C }\end{array}$ & $\begin{array}{l}\text { It is a common } \\
\text { understanding ... }\end{array}$ & $\begin{array}{l}\text { According to Bloom's } \\
\text { taxonomy, it is a common } \\
\text { understanding that to develop } \\
\text { students' HOTS teachers should } \\
\text { promote student engagement } \\
\text { with learning tasks that exceed } \\
\text { the second level 'comprehension' } \\
\text { in order to encourage } \\
\text { application, analysis, synthesis } \\
\text { and evaluation activities in } \\
\text { processing information (Zohar, } \\
\text { 1999) }\end{array}$ \\
\hline $\begin{array}{l}\text { Article } \\
\text { G }\end{array}$ & $\begin{array}{l}\text { As the most } \\
\text { widely } \\
\text { accepted ... }\end{array}$ & $\begin{array}{l}\text { As the most widely accepted } \\
\text { categorization, Bloom's } \\
\text { taxonomy can be seen as a range } \\
\text { of thinking skills which is } \\
\text { started with the lower } \\
\text { knowledge-level thinking to the } \\
\text { evaluation-level of thinking. }\end{array}$ \\
\hline $\begin{array}{l}\text { Article } \\
\text { I }\end{array}$ & It is apparent ... & $\begin{array}{l}\text { Based on her story, it is } \\
\text { apparent that the process of } \\
\text { implementation HOTS based } \\
\text { assessment was primarily done } \\
\text { by her students' difficulties in } \\
\text { choosing best answer of reading } \\
\text { test in form of multiple choice } \\
\text { tests. }\end{array}$ \\
\hline
\end{tabular}


The use of directives in research articles

The result of the questionnaires shows that $87 \%$ of the participants used directives in writing research articles. The participants stated that they used it to guide the readers in understanding the topic being discussed. A participant said that he used directives in the form of obligation modal such as should, ought to, etc. Another one said that he used it in the form of directive verbs such as consider..., pay attention more on..., etc.

From the document analysis of the research articles, directives are the most frequently used reader engagement compared to the other elements. There were 4 research articles using directives, article A, B, E, and G. The forms of appeals to shared knowledge used are presented in Table 4.

Table 3. The directives used in participants'

\begin{tabular}{|c|c|c|}
\hline Source & Form & Sentence in the article \\
\hline $\begin{array}{l}\text { Article } \\
\text { A }\end{array}$ & $\begin{array}{l}\text { It is important } \\
\text { to know ... }\end{array}$ & $\begin{array}{l}\text { Thus, it is important to know } \\
\text { the teacher's knowledge, beliefs, } \\
\text { and practices on HOTS-based } \\
\text { assessment }\end{array}$ \\
\hline $\begin{array}{l}\text { Article } \\
\text { B }\end{array}$ & $\begin{array}{lr}\text { It is } \quad \text { also } \\
\text { important } & \text { to } \\
\text { check ... } & \end{array}$ & $\begin{array}{l}\text { Thus, it is also important to check } \\
\text { the distribution of HOTs in } \\
\text { reading assessment. }\end{array}$ \\
\hline $\begin{array}{l}\text { Article } \\
\text { E }\end{array}$ & $\begin{array}{l}\text { As it can be } \\
\text { seen as the } \\
\text { example of } \ldots \\
\text { above, ... }\end{array}$ & $\begin{array}{l}\text { As it can be seen on the } \\
\text { example of excerpt on the table } \\
\text { above, the question taken from } \\
\text { university } 4 \text { admission test } \\
\text { requires the students to analyze } \\
\text { the relationship between the parts } \\
\text { before and after the word to build } \\
\text { the context of the text before } \\
\text { finding the synonym to the word } \\
\text { provided }\end{array}$ \\
\hline $\begin{array}{l}\text { Article } \\
\text { G }\end{array}$ & $\begin{array}{lr}\text { It is } \quad \text { very } \\
\text { necessary } & \text { to } \\
\text { measure ... } & \end{array}$ & $\begin{array}{l}\text { Thus, it is very necessary to } \\
\text { measure students' competence } \\
\text { and level of success of a standard } \\
\text { program that have been applied. }\end{array}$ \\
\hline
\end{tabular}

The use of questions in research articles

The result of the questionnaires shows that $52.1 \%$ of the participants used personal asides in writing research articles. The participants stated that they used it to attract the readers' interest in the topic being discussed. However, they stated that they rarely used questions in research articles. They stated that it is difficult to create attractive questions, so they preferred not using it. Furthermore, they also stated that the research articles they read did not use it, so they were not sure that it was important. The document analysis also infers the same thing. It is that the participants did not use questions in the research articles, except for research questions. However, they often used it in other academic writings, such as essays, exposition, etc.

\section{Discussion}

In this discussion, we clarify that some participants used some elements of reader engagement in their research articles -reader pronouns, personal asides, appeals to shared knowledge, directive, and questions. Based on the results, they stated that all elements were important to be applied in their research articles with some consideration. In fact, writers in all disciplines now use more of these explicit markers of reader engagement than in the past but it does not specifically increase in longer articles (Hyland, 2016). However, in this study, despite their promising beliefs of reader engagement's 
importance, the participants rarely used the reader engagement because they did not understand the concept and its use in academic writing concept.

In this present study, the participants who are in the same discipline characterize themselves, their work, and their readers in different ways. Some participants may use the elements of reader engagement with some purposes of its elements, such as to comprise the readers in their writings and acknowledge the readers' presence but reflect the writer's subjectivity or informality. Other participants told that reader engagement was important to add more explanation in the article, make the reader automatically agree with their opinion, guide readers to understand their writing, and attract readers' attention to the topic of the writing.

The use of reader engagement was achieved by the increasing use of the inclusive pronoun we (Jiang \& Ma, 2018). This finding is in line with the finding of this present study in which the writers frequently used reader pronoun we to show solidarity. It seems that the writers prefer using reader pronoun we to you. This finding somehow supports Afros \& Schryer's (2009) findings that reader pronoun you is rarely found in research articles, as similarly found in this present study. Writers probably think that pronoun you is "too direct" for the readers.

The types of reader engagement used by people vary significantly.
Furthermore, the use of reader engagement in research articles was found frequently in the discussion section (Li \& $\mathrm{Xu}, 2020)$. The result of the present study shows similar results. The research articles analysed in this present study show that the use of reader engagement was mostly found in the discussion section. It probably indicates that reader engagement is often used to negotiate the results with the previous study's results and theories.

This study also showed that the most frequently used reader engagement is reader pronouns. This result is in line with Chang's (2017) study which shows that the type of reader engagement that is most used in research articles is reader pronoun. Furthermore, the second most used reader engagement type is directive which is also in line with the results of the present study. It means that Indonesian writers have a tendency to mention the readers explicitly and instruct them to do something to guide them along the writings.

Last, this study revealed that the writers often neglect using reader engagement since they do not have adequate knowledge of how to use it effectively. This reader engagement was not taught formally in schools or universities in which this study was conducted. As a result, they rarely used it in research articles. This finding supports Amiryousefi's (2010) result that the exposure of metadiscourse, specifically reader engagement, is very limited for 
academic writing students. He found that metadiscourse, including reader engagement, was not explicitly taught in schools. As the consequence, students may unconsciously use metadiscourse in their writings, but they do not have adequate understandings of its concept. They said that the use of metadiscourse, especially reader engagement, makes their writings informal and less impersonal, which is found to be a misunderstanding (Hyland \& Jiang, 2017).

Hyland and Jiang (2016) have witnessed a growing interest in using reader engagement in research articles. They reported that in the last 50 years, writers have used more explicit reader engagement to include their readers in the discourse. Furthermore, it reported that in applied linguistic and sociology areas, there are substantial drops in the use of personal asides, appeals to shared knowledge, and reader pronouns. However, the result of this study somehow does not support his finding adequately since there is limited use of reader engagement in the participants' research articles. To know more about the increase of using reader engagement in Indonesian researchers' writings, further researches are needed to conduct.

\section{CONCLUSION}

To sum up, Indonesian master students believe that the use of reader engagement - reader pronouns, personal asides, and appeals to shared knowledge, directives, and questions - is important in research articles. They believe that research articles need to show audience awareness by using reader engagement. However, because they do not have adequate knowledge of its concept, they rarely use it in research articles. They stated that they did not know how to use reader engagement effectively. Furthermore, they used reader engagement in other academic writings besides research articles more frequently that the other reader engagement elements.

This study was done on a small number of participants and from the same discipline, which is a master degree in English Education Department. Thus, the result of this study may not be generalized in another discipline context. However, this study gives several insights on the beliefs and practices of Indonesian master students in using reader engagement in research articles. Thus, it can be used as a consideration to put metadiscourse, especially reader engagement, in formal lectures.

This study recommends similar studies with larger participants or from different disciplines to gain more valid and generalizable data. Furthermore, the studies on the use of other elements of metadiscourse are expected to conduct to provide more knowledge in using metadiscourse in an academic context. There are many things to explore more in the use of metadiscourse in writings. 


\section{ACKNOWLEDGEMENT}

I would like to thank all participants for participating and giving enormous data for this study.

\section{REFERENCES}

Afros, E., \& Schryer, C. F. (2009). Promotional (meta)discourse in research articles in language and literary studies Elena. English for Specific Purposes, 28(1), 58-68. https://doi.org/10.1016/j.esp.2008.09.0 01

Amiryousefi, M. (2010). Metadiscourse: Definitions, Issues and Its Implications for English Teachers. English Language Teaching, 3(4), 159-167.

Can, T., \& Cangır, H. (2019). A corpusassisted comparative analysis of selfmention markers in doctoral dissertations of literary studies written in Turkey and the UK. Journal of English for Academic Purposes, 42. https://doi.org/10.1016/j.jeap.2019.100 796

Chang, P. (2017). An Exploration of Interactional Metadiscourse in Architecture Research Articles. The Joint International Conference of the 8th International Conference on ESP in Asia \& the 3rd International Symposium on Innovative Teaching and Research in ESP, 1, 5-12.

Gillaerts, P., \& Velde, F. Van De. (2010). Interactional metadiscourse in research article abstracts. Journal of English for
Academic Purposes, 9(2), 128-139. https://doi.org/10.1016/j.jeap.2010.02.0 04

Handayani, A., Drajati, N. A., \& Ngadiso. (2020). Engagement in high-and lowrated argumentative essays: Interactions in Indonesian students' writings. Indonesian Journal of Applied Linguistics, 10(1), 14-24. https://doi.org/10.17509/IJAL.V10I1.2 4957

Ho, V., \& Li, C. (2018). The use of metadiscourse and persuasion: An analysis of first year university students' timed argumentative essays. Journal of English for Academic Purposes, 33, 53-68. https://doi.org/10.1016/j.jeap.2018.02.0 01

Hyland, K. (2004). Disciplinary interactions : metadiscourse in L2 postgraduate writing. 13, 133-151. https://doi.org/10.1016/j.jslw.2004.02.0 01

Hyland, K. (2005a). Metadiscourse: Exploring Interaction in Writing. Continuum.

Hyland, K. (2005b). Representing readers in writing: Student and expert practices. Linguistics and Education, 16(4), 363377.

https://doi.org/10.1016/j.linged.2006.05 .002

Hyland, K. (2005c). Stance and engagement: A model of interaction in academic discourse. Discourse Studies, 7(2), 173-192. 
https://doi.org/10.1177/1461445605050 365

Hyland, K. (2016). Constructing and interpreting teacher written feedback. 206-224.

https://doi.org/10.1017/CBO978113952 4742.013

Hyland, K., \& Jiang, F. K. (2016). “ We must conclude that ..." : A diachronic study of academic engagement. Journal of English for Academic Purposes, 24, 29-42.

https://doi.org/10.1016/j.jeap.2016.09.0 03

Hyland, K., \& Jiang, F. K. (2017). Is academic writing becoming more informal? English for Specific Purposes, 45, 4051.

https://doi.org/10.1016/j.esp.2016.09.0 01

Hyland, K., \& Zou, H. (Joanna). (2020). In the frame: Signalling structure in academic articles and blogs. Journal of Pragmatics, 165, 31-44. https://doi.org/10.1016/j.pragma.2020.0 5.002

Jiang, F. K., \& Ma, X. (2018). "As we can see": reader engagement in $\mathrm{PhD}$ candidature confirmation reports. Journal of English for Academic Purposes, 35, 1-15. https://doi.org/10.1016/j.jeap.2018.05.0 03

Kuteeva, M. (2011). Wikis and academic writing: Changing the writer - reader relationship. English for Specific
Purposes, $\quad 30(1), \quad 44-57$. https://doi.org/10.1016/j.esp.2010.04.0

07

Lee, J. J., \& Deakin, L. (2016). Interactions in L1 and L2 undergraduate student writing: Interactional metadiscourse in successful and less-successful argumentative essays. Journal of Second Language Writing, 33, 21-34. https://doi.org/10.1016/j.jslw.2016.06.0 04

Li, Z., \& Xu, J. (2020). Reflexive metadiscourse in Chinese and English sociology research article introductions and discussions. Journal of Pragmatics, 159, 47-59. https://doi.org/10.1016/j.pragma.2020.0 2.003

Loghmani, Z., Ghonsooly, B., \& Ghazanfari, M. (2020). Engagement in doctoral dissertation discussion sections written by English native speakers. Journal of English for Academic Purposes, 45, 100851.

https://doi.org/10.1016/j.jeap.2020.100 851

Miles, M. B., Huberman, M., \& Saldana, J. (2014). Qualitative Data Analysis: A Methods Sourcebook (3rd Editio). Sage Publications, Inc. 
Pedagogy: Journal of English Language Teaching, (9)2: 149-164 